\title{
S100 Proteins As an Important Regulator of Macrophage Inflammation
}

\author{
Chang Xia ${ }^{1,2}$, Zachary Braunstein ${ }^{3}$, Amelia C. Toomey ${ }^{4}$, Jixin Zhong ${ }^{2 *}$ and Xiaoquan Rao ${ }^{2 *}$ \\ ${ }^{1}$ College of Health Science and Nursing, Wuhan Polytechnic University, Wuhan, China, ${ }^{2}$ Cardiovascular Research Institute, \\ Case Western Reserve University, Cleveland, $\mathrm{OH}$, United States, ${ }^{3}$ Boonshoft School of Medicine, Wright \\ State University, Dayton, $\mathrm{OH}$, United States, ${ }^{4}$ Department of Health Sciences, University of Missouri, Columbia, MO, \\ United States
}

\section{OPEN ACCESS}

Edited by:

Leticia A. Carneiro,

Universidade Federal do Rio de

Janeiro, Brazil

Reviewed by:

Charles E. McCall,

Wake Forest Baptist

Medical Center, United States

Penghua Yang,

University of Maryland,

Baltimore, United States

*Correspondence:

Jixin Zhong

jixin.zhong@case.edu;

Xiaoquan Rao

jannet18@163.com

Specialty section:

This article was submitted to Molecular Innate Immunity,

a section of the journal

Frontiers in Immunology

Received: 06 October 2017 Accepted: 14 December 2017 Published: 05 January 2018

Citation:

Xia C, Braunstein Z, Toomey AC

Zhong $J$ and Rao X (2018) $S 100$

Proteins As an Important Regulator

of Macrophage Inflammation.

Front. Immunol. 8:1908.

doi: 10.3389/fimmu.2017.01908
The S100 proteins, a family of calcium-binding cytosolic proteins, have a broad range of intracellular and extracellular functions through regulating calcium balance, cell apoptosis, migration, proliferation, differentiation, energy metabolism, and inflammation. The intracellular functions of $\mathbf{S 1 0 0}$ proteins involve interaction with intracellular receptors, membrane protein recruitment/transportation, transcriptional regulation and integrating with enzymes or nucleic acids, and DNA repair. The S100 proteins could also be released from the cytoplasm, induced by tissue/cell damage and cellular stress. The extracellular S100 proteins, serving as a danger signal, are crucial in regulating immune homeostasis, post-traumatic injury, and inflammation. Extracellular S100 proteins are also considered biomarkers for some specific diseases. In this review, we will discuss the multi-functional roles of S100 proteins, especially their potential roles associated with cell migration, differentiation, tissue repair, and inflammation.

Keywords: S100 proteins, inflammation, tissue repair, biomarkers, inflammatory disease, macrophages

\section{INTRODUCTION}

The S100 proteins, belonging to a calcium-binding cytosolic protein family, are composed of 25 known members (1-4). They have a broad range of intracellular and extracellular functions encompassing regulation cell apoptosis, proliferation, differentiation, migration, energy metabolism, calcium balance, protein phosphorylation, and inflammation (5-8).

Based on their functional roles, s100 proteins are categorized into three main subgroups: S100 proteins that only exert intracellular functions, S100 proteins that have both intracellular and extracellular roles, and S100 proteins that mainly possess extracellular effects (7). The S100 proteins within the first subgroup only exert intracellular functions. For example, S100A1 is predominantly expressed in striated muscle (especially cardiac muscle) (9) and only exert intracellular regulatory effects such as regulating SR $\mathrm{Ca}^{2+}$ recycle and enhancing the gain of the calcium-induced calcium release (CICR) cascade (10-12). In addition to intracellular roles, some $\mathrm{S} 100$ proteins are released into the extracellular environment and may exert extracellular functions. S100B in this subgroup was known to directly interact with nuclear Dbf2-related protein kinase (NDR kinase) and block the recruitment of its substrates to NDR kinase (13). Furthermore, extracellular S100B could also activate extracellular signal-regulated protein kinase (ERK) and NFKB in chondrocytes by binding to its cell surface receptor, receptor for advanced glycation end products (RAGE) (14). The third subgroup of S100 proteins such as S100A15 mainly exerts extracellular regulatory functions. These 


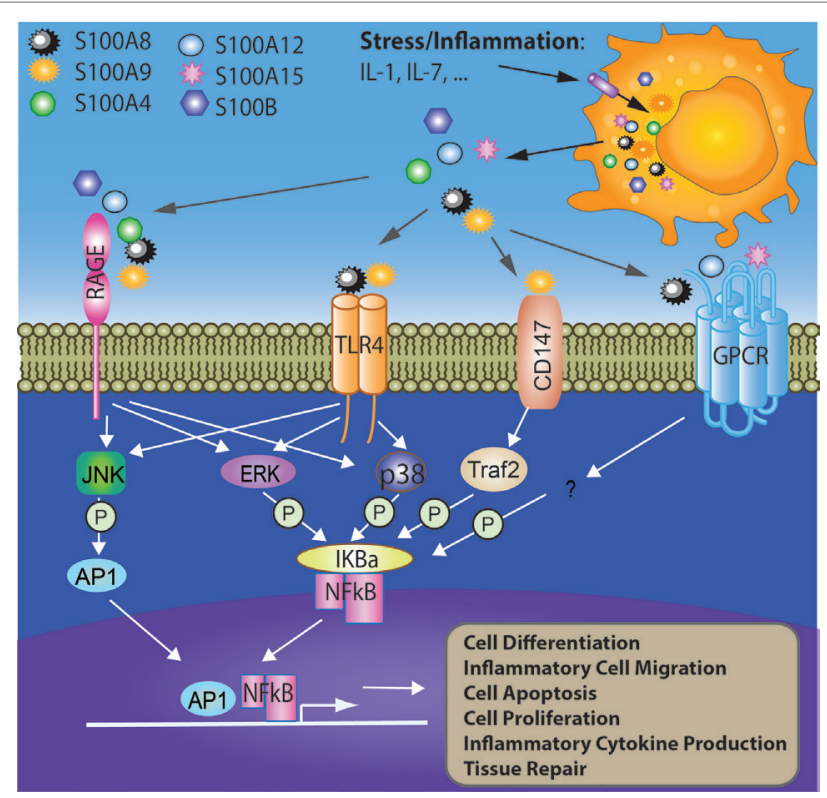

FIGURE 1 | Involvement of S100 proteins in stress and inflammationmediated responses. Cell stress or inflammation induce the release of $\mathrm{S} 100$ proteins to acellular compartment where they bind cell surface receptors such as RAGE, TLR4, CD147, and GPCR. The interactions between $\mathrm{S} 100$ proteins and their receptors activate intracellular signaling pathways such as AP1 and NFkB, which further initiates multiple cellular processes such as cell differentiation, migration, apoptosis, proliferation, and inflammation. AP1, activator protein 1; ERK, extracellular signal-regulated protein kinase; GPCR, G-protein-coupled receptor; IL-1, interleukin 1; IL-7, interleukin 7; IKB $\alpha$, nuclear factor of kappa light polypeptide gene enhancer in B-cells inhibitor alpha; JNK, c-Jun N-terminal kinase; P38, p38 mitogen-activated protein kinase; RAGE, receptor for advanced glycation end products; TLR4, toll-like receptor 4; Traf2, TNF receptor-associated factor 2.

of S100 proteins are considered as potential therapeutic targets for various human disorders, including arthritis, cancer, and Alzheimer's disease $(15,16)$.

S100 proteins are involved in multiple intracellular functions which include: interacting with intracellular receptors or molecule subunits (17), membrane protein recruitment and transportation, transcriptional regulation $(18,19)$, regulating enzymes, nucleic acids, and DNA repair $(20,21)$ (Figure 1). There are two critical steps for S100 protein activation: $\mathrm{Ca}^{2+}$ binding (22) and homoor hetero-dimer formation (23). Each S100 protein forming the dimer participates in ion $\left(\mathrm{Ca}^{2+}, \mathrm{Zn}^{2+}\right.$, or $\left.\mathrm{Cu}^{2+}\right)$ binding. $\mathrm{Ca}^{2+}$ also contributes to the formation of $\mathrm{S} 100$ protein oligomers, especially calprotectin (S100A8/A9 tetramer) $(22,24,25)$.

When released to the extracellular space, S100 proteins have crucial activities in the regulation of immune homeostasis, post-traumatic injury, and inflammation. S100 proteins trigger inflammation through interacting with receptors RAGE and TLR4 (26). Increasing evidence has demonstrated that calprotectin (S100A8/A9) is an endogenous agonist of TLR4 (26). Binding to TLR4 initiates a signaling cascade and regulates inflammation, cell proliferation, differentiation, and tumor development in an NF-кB-dependent manner (8, 26-28). Apart from TLR4, RAGE has also been suggested to bind S100 proteins such as S100A7, S100A12, S100A8/A9, and S100B (27, 29-31). By interacting with RAGE, S100 proteins activate NF- $\kappa \mathrm{B}$, inducing the production of pro-inflammatory cytokines leading to the migration of neutrophils, monocytes, and macrophages $(30,31)$. In addition to the NF- $\kappa \mathrm{B}$ pathway, MAP kinase-mediated signaling is also induced by $\mathrm{S} 100$ proteins such as S100P $(32,33)$. Interestingly, S100A6 activates RAGE and promotes apoptosis, while S100B inactivates RAGE by interacting with the basic fibroblast growth factor and its receptor $(14,34)$. Extracellular $\$ 100$ proteins may regulate the apoptosis, proliferation, differentiation, and migration of a number of cell types including monocytes, macrophages, neutrophils, lymphocytes, myoblast, epithelial cells, endothelial cells, smooth muscle cells, neurons, and fibroblasts. In this review, we aim to summarize the immune regulatory role of S100 proteins and their potential involvement in inflammatory regulation, tissue repair, and tumorigenesis.

\section{S100 GENES AND MOLECULAR STRUCTURE}

Each S100 family protein is encoded by a separate gene. Most S100 genes are located within the chromosome 1q21 with a few exceptions. For example, S100A11P is located within chromosome $7 \mathrm{q} 22-\mathrm{q} 3, \mathrm{~S} 100 \mathrm{~B}$ in located within chromosome 21q22, $\mathrm{S} 100 \mathrm{P}$ is located in chromosome $4 \mathrm{p} 16, \mathrm{~S} 100 \mathrm{G}$ is located in chromosome Xp22, and S100Z is located with chromosome $5 \mathrm{q} 13$ (5). The sequence homology among S100 proteins varies from 22 to $57 \%$, which is mainly due to the variance at the hinge region and C-terminus, the regions associated with their function (35).

S100 proteins are small proteins with a molecular weight of $10-12 \mathrm{kDa}$. Each S100 protein consists of two EF-hand helixloop-helix structural motifs, which are arranged in a back-toback manner and linked with a flexible hinge (23). The activity of the proteins is regulated by metal ions (such as calcium, zinc, and copper), which modulates the folding and oligomerization of the protein $(36,37)$.

\section{EXPRESSION PATTERN AND REGULATION}

Epigenetic mechanisms play a key role in the regulation of S100 protein expression. S100A3, S100A10, S10011, and S100P could be detected in various medulloblastoma cell lines treated with DNA de-methylation (38). It is reported that DNA hypomethylation could induce S100A6 overexpression in gastric cancer. Lower levels of $\mathrm{CpG}$ methylation in the first intron and second exon regions of the S100A6 gene, accompanied by higher levels of acetylated histone $\mathrm{H} 3$ binding to the promoter, have been reported in the gastric cancer tissues (39). Lower methylation in the proximal promoter region of the S100P gene was also found in prostate cancer cell lines (40). The expression of S100 proteins may also be regulated by micro RNAs, although further studies are needed to provide direct evidence. NFAT5, a transcription factor that initiates S100A4 expression (41), is regulated by miR568 (42). 
The expression of $\mathrm{S} 100$ proteins is strictly regulated to maintain immune homeostasis (7, 43). S100A8 and S100A9 are predominately expressed in monocytes, neutrophils, and dendritic cells $(44,45)$. However, they are also expressed in various other types of cells upon activation, such as fibroblasts (46), mature macrophages (47), vascular endothelial cells (48-50), and keratinocytes (51). In neutrophils, $45 \%$ of the cytosolic proteins are constituted with S100A8 and S100A9, whereas the proportion is only $1 \%$ in monocytes (52). The expression levels in different monocyte subsets also vary. The level of S100A8 mRNA is higher in classical CD $14^{+} / \mathrm{CD} 16^{-}$human monocytes when compared to non-classical CD $14^{+} \mathrm{CD} 16^{+}$monocytes (47).

Increasing evidence indicates that the expression of most S100 proteins is different between physiological and pathological conditions. The expression of S100A8 and S100A9 could be upregulated by a number of conditions such as oxidative stress, specific cytokines, and growth factors in many types of cells (53). S100A12 is mainly expressed in neutrophils, monocytes, and early macrophages $(53,54)$, but it can also be detected in endothelial cells, keratinocytes, epithelial cells, and proinflammatory macrophages under inflammatory conditions (51, 55-58). In human epidermal keratinocytes, interleukin (IL)$1 \alpha$ induces a significant increase of S100A9 expression by the p38 MAPK pathway (59). The expression of S100A5 is upregulated in bladder cancers (60). Pro-inflammatory cytokines could increase S100A7 expression in human breast cancer (61). IL-17, IL-22, and bacterial products (e.g., flagellin) can enhance S100A7 expression in keratinocytes (62). IL-6 and IL-8 released from myofibroblasts could also trigger the upregulation of S100A8/A9 in tumor-infiltrated myeloid cells (63). S100A9 was significantly higher in the peripheral blood in patients with implant-associated osteomyelitis. S100A9 expressing cells were also increased in tissue biopsies from patients with implant infections, compared with the non-infected individuals (64).

\section{S100 PROTEINS FUNCTION AS DAMAGE-ASSOCIATED MOLECULAR PATTERN (DAMP) MOLECULES}

In addition to serving as calcium-binding proteins, $\mathrm{S} 100$ proteins were later discovered as DAMP molecules $(26,65,66)$. DAMPs were considered as a series of intracellular molecules linked with cell death and tissue damage through inducing a rapid inflammatory response or production biologically active molecules $(67,68)$. DAMPs are biomolecules that are released from damaged or stressed cells and could act as endogenous danger signal to activate inflammatory response (69). S100 proteins could be released from the cells after cell damage/stress or activation of phagocytes such as neutrophils and macrophages. The extracellular S100 proteins then become danger signals and activate immune cells and endothelial cells by binding to the pattern recognition receptors such as TLRs and RAGE.

They play an important role in modulating inflammatory responses (70). Once released from the cell, calprotectins function as an endogenous agonist to bind TLR4 (S100A8/A9 and S100A12) (26) and RAGE (S100A8/A9 and S100A7) $[(6,31,71)$
\#3535]. In the site of inflammation, calprotectin acts as a chemotactic factor by inducing neutrophils adhesion (72). Furthermore, S100A8/A9 induces apoptosis and autophagy in various cell types such as lymphocytes, macrophages, endothelial cells, and tumor cells (73). It has been shown that reactive oxygen species (ROS) is the critical factor in S100A8/A9-induced cell death and involves BNIP3. The increase of ROS production in mitochondria subsequently causes mitochondrial damage and lysosomal activation (73).

\section{S100 PROTEINS IN MACROPHAGES MIGRATION, INVASION, AND DIFFERENTIATION}

It is widely accepted that macrophages contribute to immune defense, immune regulation, and tissue repair. Based on their cytokine production and activation conditions, macrophages are categorized into two populations: pro-inflammatory M1 (classically activated macrophage) and anti-inflammatory M2 (alternatively activated macrophage). Calprotectin could induce pro-inflammatory cytokine production in monocytes and macrophages through NF- $\kappa B$ and p38 MAPK pathways (74). An increasing number of findings demonstrate that $\mathrm{S} 100$ proteins contribute to the adhesion and migration of leukocytes. For example, the release of S100A8/A9 has been suggested to facilitate monocyte and neutrophil transmigration $(75,76)$. The S100A8/ A9 heterodimer enhances the expression of $\beta 2$ integrin CD11b and the ability of adhesion in phagocytes $(72,77)$. Moreover, the response of S100A9 ${ }^{-1-}$ monocytes to chemotaxis was reduced when compared with wild-type cells. For example, IL 8-induced CD11b upregulation was abolished in S100A9 ${ }^{-/-}$monocytes and neutrophils (78). S100A4 has also been shown to interact with cytoskeletal proteins to promote cell migration and deletion of s100a4, which leads to the deficiency of macrophage migration and chemotactic reactions (79-81). S100A12 induced the production of pro-inflammatory cytokine IL- 6 and IL- 8 in both a dose-dependent and time-dependent manner. This was critical to regulate the recruitment of monocytes and TNF- $\alpha$ release (82).

The intimate relationship between macrophages and cancer cells plays a crucial role in tumor growth and metastasis. Tumor associated macrophages influence tumor growth by modulating local inflammation, inhibiting antitumor immunity, and stimulating angiogenesis (83-85). It is commonly accepted that macrophages contribute to tumor growth and invasion. They are recruited to the site of tumors via chemoattractants such as CCL3-8, vascular endothelial growth factor (VEGF), and macrophage inflammatory protein-1 alpha (MIP-1 $\alpha$ ) (86). The monocytes or macrophages tend to differentiate into the M2 macrophage phenotype rather than the tumoricidal M1 phenotype, producing pro-tumor cytokines, such as macrophage colonystimulating factor, IL-10, IL-4, and IL-13 $(83,87,88)$. S100A10 was shown to mediate the migration of macrophages to the tumor site. Tumor growth was reduced in S100A10-null mice, compared with wild-type mice, and was accompanied by less macrophages within the tumor. There were many macrophages throughout the tumor in wild-type mice, where macrophages were observed 
only around the absolute tumor tissue border in S100A10-null mice (89). Intraperitoneal injection of wild-type macrophages restored macrophage density within the tumor, but injection of S100A10-deficient macrophages did not. Interestingly, intratumoral injection of macrophages of either genotype could rescue tumor growth, suggesting that $\mathrm{S} 100 \mathrm{~A} 10^{-/-}$macrophages still have the ability to stimulate tumor growth but lack the ability to invade into the tumor (89). Another study showed that S100A10 deficiency decreased plasmin generation and matrix metalloproteinase 9 activation in macrophages, both of which are associated with macrophage invasion and migration (90).

Downregulation of S100A8 and S100A9 is associated with the differentiation of myeloid cells toward dendritic cells and macrophages $(91,92)$. S100A8 and S100A9 are co-expressed in fetal myeloid progenitors, with its expression level associated with the development of the myeloid lineage (93). They are highly expressed in monocytes and neutrophils. However, the expressions of S100A8 and S100A9 are lost when monocytes terminally differentiate into tissue macrophages (93). Recent data have shown that $\mathrm{S} 100 \mathrm{~A} 8$ can be induced by oxidative stress in macrophages in an IL-10-dependent manner (51). Interestingly, S100A8/A9 has also been shown to control the cell cycle (94). S100A9 inhibited myeloid cells differentiation through generation of ROS (92). S100A9 is able to induce the differentiation of monocytes toward the osteoclast type in in vitro culture experiments and S100A9 derived from neutrophils and S100A9-induced osteoclast generation were considered as important reasons for bone degradation in infectious osteomyelitis (95). S100A8 and S100A9 have also been shown to mediate the arresting effect of TNF- $\alpha$ on the differentiation of immature myeloid-derived suppressor cells into dendritic cells and macrophages in a RAGE-dependent manner (96). Consistent with this finding, IL-6 and IL-8 released from myofibroblasts in tumor microenvironment upregulate S100A8/ S100A9 in myeloid cells and induce the differentiation of myeloid cells into S100A8/S100A9-expressing myeloid-derived suppressor cells and M2 macrophages (63).

\section{ROLE OF S100 PROTEINS IN TISSUE REPAIR}

Damage-associated molecular pattern molecules play a critical role in tissue repair. S100A7, S100A8/A9, S100A12, and S100A15, well-documented DAMPs, have been shown to participate inflammatory tissue damage and tissue repair. The link between S100A12 and the severity of coronary and carotid atherosclerosis has been evidenced by multiple human studies (97-99). S100A7 is highly expressed in the skin, and the expression is increased in inflamed skin, which has been shown to be induced by pro-inflammatory cytokines (IL-17 and IL-22) and bacterial products such as flagellin (62), that the increase of S100A7 has been associated with multiple inflammatory skin diseases, such as psoriasis and atopic dermatitis $(62,100)$. Similarly, the expression of S100A15 was amplified in the epidermis of psoriatic lesions and acted as chemoattractants for immune cells (101). S100A8/ A9 exerts anti-inflammatory function in healthy state, while oxidative stress-associated pathological conditions activate their pro-inflammatory functions (102). Increased plasma S100A8/A9 levels have been associated with atherogenesis, plaque vulnerability, myocardial infarction (MI), cardiovascular death, and heart failure. In a mouse model of angiotensin-induced cardiac damage, it was shown that S100A8/A9 released by granulocytes upregulated pro-inflammatory gene expression and induced the release of cytokines and chemokines in a RAGE-dependent manner. This process promoted myocardial tissue inflammation and fibrotic scar formation $(103,104)$. In a mouse model of collagenase-induced arthritis, the expression of S100A8 and S100A9 in synovial was upregulated in wild-type mice. In addition, S100a $9^{-/-}$mice were protected from collagenase-induced synovitis, cartilage degradation, and osteophyte formation $(105,106)$. S100A9 antibodies could block the accumulation of fibroblasts and decrease fibrosis in local inflammatory microenvironment (104). In contrast, S100A 1 or S100A4, released following MI, has a beneficial effect following heart injury by promoting muscle tissue repair and maintaining contractility $(107,108)$.

Binding of S100B to RAGE and the subsequent increase of angiogenic factor VEGF have been shown to be essential in the development of macular degeneration (109). In addition, S100B activates the Ras-MEK-ERK1/2-NF- $\mathrm{B}$ pathway in neural cells and leads to the activation of small GTPases, Rac1/Cdc 42, and neurite growth (110). In vascular smooth muscle cells, S100B induces the upregulation of ROS and recruits JAK2 and STAT3, which results in the proliferation of vascular smooth muscle cells (111). Similarly, S100B also increased cellular proliferation though activating the Phosphatidylinositol-4,5-bisphosphate 3-kinaseAKT pathway in a RAGE-dependent manner (14). On the other hand, S100B could induce apoptosis by increasing production of ROS and the release of cytochrome-c from mitochondria (110). High levels of S100B are released from injured cardiomyocytes following MI and could promote cell apoptosis through RAGE. Also, S100B released from injured skeletal muscle tissue could stimulate myoblast proliferation but inhibit myoblast differentiation by activating bFGF/FGFR1 signaling $(112,113)$. However, the regeneration effects of $\mathrm{S} 100 \mathrm{~B}$ on the injured myoblasts are strongly dependent on cell density, because it triggers RAGE, but not bFGF/FGFR1 signaling, at an early stage of low-density myoblast differentiation (114).

\section{THE ROLE OF S100 PROTEINS IN INFLAMMATORY DISEASES}

S100 proteins, particularly calgranulins, play a significant role in mediating innate and acquired immune responses, which contribute to the development of chronic inflammatory diseases.

Calgranulins are associated with joint inflammation in patients with rheumatoid arthritis (RA) (115). The level of S100A8/ A9 in the serum and synovial fluid was significantly increased in RA $(116,117)$. Recent findings showed that S100A8/A9 was upregulated in early but not late phase osteoarthritis (OA) (118). S100A8/A9 plasma levels were increased at baseline in human OA participants. Meanwhile, osteophyte size was drastically reduced in S100A9 ${ }^{-/-}$mice-induced OA (106). It has also been confirmed that S100A8/A9 contributes to cartilage degradation 
and development of inflammatory arthritis in an antigen-induced arthritis model (119). Similar to S100A8/A9, human S100A7 and S100A15 were first confirmed as over-expressed in psoriatic plaques (120). Increasing evidence supports an association of S100A7 with several inflammatory skin diseases, including psoriasis and atopic dermatitis $(62,100)$. Evidence strongly indicates that S100A8/A9 levels are higher in hypercalprotectinemia, an extremely rare inflammatory disorder (121-123). Although the mechanism is still unclear, it is possible that the releasing of extracellular S100A8/A9 is dysregulated, which accounts for the abnormal increase of calprotectin and subsequent hyperactive inflammatory reaction. It is suggested that S100 proteins are involved in interacting with both the immune system and the pathogen. S100A12 plays a key role in fighting infections. For example, it has been shown that S100A12 plays a critical role in anti-parasite responses (124). In addition to directly killing Mycobacterium tuberculosis and Mycobacterium leprae, S10012 is also required for TLR2/1L- and IFN- $\gamma$-induced antimicrobial activity against Mycobacterium (125). Haley et al. also showed that S100A12 can help to repress the biogenesis and activity of $H$. pylori cag type IV secretion system by binding nutrient zinc, which results in suppressed bacterial growth and viability (126).

S100A8, S100A9, and S100A12 are abundantly expressed by neutrophils. Evidence indicates that these three members of S100 proteins are released by neutrophils, inducing MUC5AC production in airway epithelial cells through activating TLR4 and RAGE signaling pathway. This reveals the relationship between chronic neutrophilic inflammation and obstructive airway diseases such as severe asthma, COPD, and cystic fibrosis (127). In correlation with their role in the development of chronic inflammation, S100A8/A9 also participates in the hyperglycemia-induced increase of myelopoiesis occurring in a RAGE-dependent manner in diabetic mice (128). Interestingly, the amount of circulating monocytes and neutrophils were decreased when antidiabetic treatment normalized the glycemic index of $\mathrm{Ldlr}^{-/-}$atherosclerotic mice, which might explain the increased severity of atherosclerosis found in patients with diabetes (128). In accordance with these findings, increased serum concentrations of S100A8/A9 were detected in obese individuals (129). Furthermore, the expression of the macrophage marker CD68 was increased in the visceral adipose tissue (130). Some research of dipeptidyl peptidase- 4 inhibitors for the treatment of type 2 diabetes mellitus indicates that vildagliptin could increase the mRNA expression levels of S100A9 and TNF- $\alpha$ in human hepatocytes. In addition, it may induce the release of S100A8/ A9 complex from HL-60 cells via TNF- $\alpha$-independent manner, which might be a contributing factor of vildagliptin-associated liver dysfunction (131).

\section{S100 PROTEINS AS BIOMARKERS IN SPECIFIC DISEASES}

Extracellular S100 proteins are involved in the activation of G protein-coupled receptors, heparan sulfate proteoglycans or $\mathrm{N}$-Glycans, and scavenger receptors in autocrine and paracrine manners $(132,133)$. Since S100A proteins can be detected in body fluids, such as urine, cerebrospinal fluid, serum, sputum, and feces, extracellular S100 proteins are considered as biomarkers associated with certain diseases (134-137).

It has been suggested that S100A12, S100A8/A9, and S100B are linked to specific diseases and conditions such as autoinflammatory diseases, stroke, and trauma (138). The level of S100A12 in the blood is increased in the patients with diabetes, which is correlated with a higher risk of cardiovascular disease development (139). Bogdanova et al. detected the serum concentration of S100A12 and other acute-phase inflammatory markers in thirty-five patients with periodic disease (PD) (140). The level of S100A12 in PD was significantly higher compared to other familial periodic fevers. S100A12 was more sensitive to assess the subclinical activity of autoinflammatory diseases, when compared to other inflammatory biomarkers such as neutrophil counts, fibrinogen, C-reactive protein (CRP), and erythrocyte sedimentation rate (140). Similarly, the serum concentrations of S100A12, as a novel biomarker, were shown to be upregulated in patients with Familial Mediterranean fever in comparison to controls (141).

The plasma concentrations of S100A9 were significantly higher in patients with implant-associated infectious osteomyelitis when compared to patients with sterile inflammation or healthy individuals. In addition, S100A9 was associated with osteoclast generation and bone degradation. Therefore, it could serve as a novel diagnostic marker to aid in the differential diagnosis (95). Similarly, serum levels of S100A8 and S100A9 were dramatically increased in IL-1 $\mathrm{Ra}^{-1-}$ mice and contributed to bone erosion, cartilage damage, and synovial inflammation. Thus, they can be considered as a systemic or local biomarker to evaluate the extent of inflammation and inflammatory joint destruction in seronegative arthritis (142). It was shown that the expression of S100A8/ A9 was high in human atherosclerotic lesions and the blood levels were also increased in the patients with coronary artery diseases (CAD), which implied S100A8/A9 might act as a biomarker for cardiovascular events (143). Recent research has shown similar findings that serum S100A8/A9 levels were elevated in $178 \mathrm{CAD}$ patients with unstable angina pectoris or acute myocardial infarction, and the level of S100A8/A9 was significantly positively linked with CRP $(P<0.01)(144)$. These clinical data suggest that S100A8/A9 may become a novel biomarker for CAD (139).

In addition, more studies explored the value S100A8/A9 as a predictive biomarker for autoimmune diseases. In RA, S100A8/A9 was suggested as a potential biomarker in predicting clinical response to monitor treatment $(145,146)$. Some clinical investigations have indicated that S100A8/A9 levels might be a more sensitive predictor for monitoring synovial inflammation in RA patients when compared with other markers such as CRP levels (147).

The study by Shakeri et al. suggested that $\mathrm{S} 100 \mathrm{~B}$ protein could be used as a posttraumatic biomarker for predicting brain death in severely injured patients with exclusive head trauma during the first $6 \mathrm{~h}$ after trauma, but found no relationship between S100 B levels and death (148). Pelinka et al. confirmed that in vitro S100 B concentrations increased significantly in rats with femoral fractures but not head injury (149). Interestingly, adverse results indicated that there was no difference in S100 B concentrations 
between patients with and without head injury (150). S100B has also been considered as a prognostic marker of the acute phase of neurologic damage (151), predicting the outcome of traumatic brain injury and large volume cerebral infarction $(152,153)$. The level of serum S100B in ischemic stroke implied a worse outcome secondary to the stroke $(154,155)$. This research demonstrates that $\mathrm{S} 100 \mathrm{~B}$ is correlated to trauma and a worse long-term outcome. S100B has recently been confirmed to be associated with some genetic disorders and was found to be over-expressed in patients with Down syndrome $(156,157)$. There was also study showing that S100B may be one of the best biomarkers of melanoma (158).

\section{S100 PROTEINS AS THERAPEUTIC TARGETS IN DISEASE}

Although direct clinical evidence is limited, increasing studies indicate that $\mathrm{S} 100$ proteins may also serve as a therapeutic target for certain disease conditions. As mentioned above, S100 proteins are involved in a number of diseases including inflammatory disease. It has been reported that multiple anti-allergic drugs such as amlexanox, cromolyn, and tranilast are able to bind S100A12 and S100A13, and block downstream RAGE signaling (159). Therefore, these drugs may serve as a therapeutic approach to target S100 proteins. Multiple S100 proteins such as S100A4 (160) and S100B (161) have been shown to participate in the neoplastic disorders by binding to P53 and suppressing its phosphorylation (162). Therefore, efforts are being made to restore P53 function by targeting S100 proteins (163). In an in vitro study, Most et al. demonstrated that extracellular S100A1 is endocytosed by the neonatal ventricular cardiomyocytes protects cardiomyocytes from 2-deoxyglucose and oxidative stress-induced apoptosis via activation of ERK (164). Adeno-associated virus-mediated S100A1 gene transfer in failing cardiomyocytes was also shown to be able to restore the contractile function, suggesting a potential implication of AAV-mediated S100A1 gene therapy in heart failure $(165,166)$. Despite the promising potentials, the feasibility and safety of these approaches and issues such as how to control and keep expression levels in the therapeutic window need to be further investigated (166).

\section{CONCLUSION}

Evidence strongly supports that S100 proteins, as a remarkable multifunctional proteins family, are involved in the regulation of several important biological processes such as the inflammatory response, protecting the intra- and extracellular environments during infection, cell proliferation and differentiation, tumor growth and metastasis, cell apoptosis, energy, and glutathione metabolism.

\section{REFERENCES}

1. Moore BW. A soluble protein characteristic of the nervous system. Biochem Biophys Res Commun (1965) 19:739-44. doi:10.1016/0006-291X(65)90320-7

2. Moore BW, McGregor D. Chromatographic and electrophoretic fractionation of soluble proteins of brain and liver. J Biol Chem (1965) 240:1647-53.
However, the activities of all members S100 proteins depend on the cell-specific expression patterns and binding targets even the local microenvironment. Extracellular effects of S100 proteins interact with receptors including TLR-4, RAGE, and heparan sulfate proteoglycans during infection and inflammation which associated with the pathogenesis of inflammatory such as autoimmune disease, infectious diseases, allergy, tumorigenesis and metastasis, and anti-microbial disease. Extracellular S100 proteins can also contribute to the regulation of tissue development and regeneration or repair, which is essential for elucidating their role in the pathological procession of tissue damage, cell apoptosis, or tissue repair.

Although growing evidence has begun to show the regulation of S100 proteins in detail which improves our understanding of how immune homeostasis is maintained during the development of S100 protein-associated disease, there are certain gaps in our understanding of the role of S100 proteins in pathophysiology. Among 25 known members of S100 family, only limited number of S100 proteins such as S100A8 and S100A9 have been well documented and the functional roles of other members are underappreciated. In addition, further studies are required to fully reveal the underlying mechanisms by which $\mathrm{S} 100$ proteins participate in a variety of disease conditions. For instance, a role of S100P has been reported in leukemia (167), while the exact function of S100P in leukemia and the signal pathways involved in this process are not completely understood. Also, the direct clinical evidence of the therapeutic potential of S100 proteins is limited at current stage. Therefore, future directions in this area could focus on the development of therapeutic approaches targeting S100 proteins, verification of the therapeutic potential of S100 proteins in both preclinical and clinical settings, and elucidation of the underlying mechanisms.

\section{AUTHOR CONTRIBUTIONS}

$\mathrm{CX}$ and JZ reviewed the literature and wrote the first draft. ZB, AT, $\mathrm{JZ}$, and XR reviewed the literature and finalized the manuscript.

\section{FUNDING}

This work was supported by grants from National Natural and Scientific Foundation of China (81670431 and 81101247), NIH (K99ES026241 and K01DK105108), AHA (17GRNT33670485), and Natural Science Foundation of Zhejiang Province (No. Y2110580). These funding supports did not lead to any conflict of interests regarding the publication of this manuscript.

3. Moore BW, Perez VJ, Gehring M. Assay and regional distribution of a soluble protein characteristic of the nervous system. J Neurochem (1968) 15:265-72. doi:10.1111/j.1471-4159.1968.tb11610.x

4. Potts BC, Smith J, Akke M, Macke TJ, Okazaki K, Hidaka H, et al. The structure of calcyclin reveals a novel homodimeric fold for S100 Ca(2+)-binding proteins. Nat Struct Biol (1995) 2:790-6. doi:10.1038/nsb0995-790 
5. Marenholz I, Heizmann CW, Fritz G. S100 proteins in mouse and man: from evolution to function and pathology (including an update of the nomenclature). Biochem Biophys Res Commun (2004) 322:1111-22. doi:10.1016/j. bbrc.2004.07.096

6. Leclerc E, Fritz G, Vetter SW, Heizmann CW. Binding of S100 proteins to RAGE: an update. Biochim Biophys Acta (2009) 1793:993-1007. doi:10.1016/j. bbamcr.2008.11.016

7. Donato R, Cannon BR, Sorci G, Riuzzi F, Hsu K, Weber DJ, et al. Functions of S100 proteins. Curr Mol Med (2013) 13:24-57. doi:10.2174/1566524011 307010024

8. Gross SR, Sin CG, Barraclough R, Rudland PS. Joining S100 proteins and migration: for better or for worse, in sickness and in health. Cell Mol Life Sci (2014) 71:1551-79. doi:10.1007/s00018-013-1400-7

9. Zimmer DB, Landar A. Analysis of S100A1 expression during skeletal muscle and neuronal cell differentiation. J Neurochem (1995) 64:2727-36. doi:10.1046/j.1471-4159.1995.64062727.x

10. Most P, Bernotat J, Ehlermann P, Pleger ST, Reppel M, Borries M, et al. S100A1: a regulator of myocardial contractility. Proc Natl Acad Sci U S A (2001) 98:13889-94. doi:10.1073/pnas.241393598

11. Most P, Pleger ST, Volkers M, Heidt B, Boerries M, Weichenhan D, et al. Cardiac adenoviral S100A1 gene delivery rescues failing myocardium. J Clin Invest (2004) 114:1550-63. doi:10.1172/JCI21454

12. Most P, Boerries M, Eicher C, Schweda C, Volkers M, Wedel T, et al. Distinct subcellular location of the Ca2+-binding protein S100A1 differentially modulates Ca2+-cycling in ventricular rat cardiomyocytes. J Cell Sci (2005) 118:421-31. doi:10.1242/jcs. 01614

13. Bhattacharya S, Large E, Heizmann CW, Hemmings B, Chazin WJ. Structure of the Ca2+/S100B/NDR kinase peptide complex: insights into S100 target specificity and activation of the kinase. Biochemistry (2003) 42:14416-26. doi:10.1021/bi035089a

14. Leclerc E, Fritz G, Weibel M, Heizmann CW, Galichet A. S100B and S100A6 differentially modulate cell survival by interacting with distinct RAGE (receptor for advanced glycation end products) immunoglobulin domains. J Biol Chem (2007) 282:31317-31. doi:10.1074/jbc.M703951200

15. Marshak DR, Pena LA. Potential role of S100 beta in Alzheimer's disease: an hypothesis involving mitotic protein kinases. Prog Clin Biol Res (1992) 379:289-307.

16. Griffin KA, Bidani AK. Progression of renal disease: renoprotective specificity of renin-angiotensin system blockade. Clin J Am Soc Nephrol (2006) 1:1054-65. doi:10.2215/CJN.02231205

17. Donato R. S100: a multigenic family of calcium-modulated proteins of the EF-hand type with intracellular and extracellular functional roles. Int J Biochem Cell Biol (2001) 33:637-68. doi:10.1016/S1357-2725(01)00046-2

18. Komatsu K, Kobune-Fujiwara Y, Andoh A, Ishiguro S, Hunai H, Suzuki N, et al. Increased expression of S100A6 at the invading fronts of the primary lesion and liver metastasis in patients with colorectal adenocarcinoma. $\mathrm{Br}$ J Cancer (2000) 83:769-74. doi:10.1054/bjoc.2000.1356

19. Melle C, Ernst G, Schimmel B, Bleul A, Von Eggeling F. Colon-derived liver metastasis, colorectal carcinoma, and hepatocellular carcinoma can be discriminated by the $\mathrm{Ca}(2+)$-binding proteins S100A6 and S100A11. PLoS One (2008) 3:e3767. doi:10.1371/journal.pone.0003767

20. Berge G, Maelandsmo GM. Evaluation of potential interactions between the metastasis-associated protein S100A4 and the tumor suppressor protein p53. Amino Acids (2011) 41:863-73. doi:10.1007/s00726-010-0497-3

21. Mishra SK, Siddique HR, Saleem M. S100A4 calcium-binding protein is key player in tumor progression and metastasis: preclinical and clinical evidence. Cancer Metastasis Rev (2012) 31:163-72. doi:10.1007/s10555-011-9338-4

22. Brophy MB, Hayden JA, Nolan EM. Calcium ion gradients modulate the zinc affinity and antibacterial activity of human calprotectin. J Am Chem Soc (2012) 134:18089-100. doi:10.1021/ja307974e

23. Fritz G, Botelho HM, Morozova-Roche LA, Gomes CM. Natural and amyloid self-assembly of $\mathrm{S} 100$ proteins: structural basis of functional diversity. FEBS $J$ (2010) 277:4578-90. doi:10.1111/j.1742-4658.2010.07887.x

24. Korndorfer IP, Brueckner F, Skerra A. The crystal structure of the human (S100A8/S100A9)2 heterotetramer, calprotectin, illustrates how conformational changes of interacting alpha-helices can determine specific association of two EF-hand proteins. J Mol Biol (2007) 370:887-98. doi:10.1016/j. jmb.2007.04.065
25. Hayden JA, Brophy MB, Cunden LS, Nolan EM. High-affinity manganese coordination by human calprotectin is calcium-dependent and requires the histidine-rich site formed at the dimer interface. J Am Chem Soc (2013) 135:775-87. doi:10.1021/ja3096416

26. Vogl T, Tenbrock K, Ludwig S, Leukert N, Ehrhardt C, Van Zoelen MA, et al. Mrp8 and Mrp14 are endogenous activators of toll-like receptor 4, promoting lethal, endotoxin-induced shock. Nat Med (2007) 13:1042-9. doi:10.1038/ nm1638

27. Turovskaya O, Foell D, Sinha P, Vogl T, Newlin R, Nayak J, et al. RAGE, carboxylated glycans and S100A8/A9 play essential roles in colitis-associated carcinogenesis. Carcinogenesis (2008) 29:2035-43. doi:10.1093/carcin/ bgn 188

28. Sorci G, Riuzzi F, Giambanco I, Donato R. RAGE in tissue homeostasis, repair and regeneration. Biochim Biophys Acta (2013) 1833:101-9. doi:10.1016/j. bbamcr.2012.10.021

29. Hofmann MA, Drury S, Fu C, Qu W, Taguchi A, Lu Y, et al. RAGE mediates a novel proinflammatory axis: a central cell surface receptor for S100/calgranulin polypeptides. Cell (1999) 97:889-901. doi:10.1016/ S0092-8674(00)80801-6

30. Gebhardt C, Riehl A, Durchdewald M, Nemeth J, Furstenberger G, MullerDecker K, et al. RAGE signaling sustains inflammation and promotes tumor development. J Exp Med (2008) 205:275-85. doi:10.1084/jem.20070679

31. Ghavami S, Rashedi I, Dattilo BM, Eshraghi M, Chazin WJ, Hashemi M, et al. S100A8/A9 at low concentration promotes tumor cell growth via RAGE ligation and MAP kinase-dependent pathway. J Leukoc Biol (2008) 83:1484-92. doi:10.1189/jlb.0607397

32. Maletzki C, Bodammer P, Breitruck A, Kerkhoff C. S100 proteins as diagnostic and prognostic markers in colorectal and hepatocellular carcinoma. Hepat Mon (2012) 12:e7240. doi:10.5812/hepatmon.7240

33. Arumugam T, Ramachandran V, Sun D, Peng Z, Pal A, Maxwell DS, et al. Designing and developing S100P inhibitor 5-methyl cromolyn for pancreatic cancer therapy. Mol Cancer Ther (2013) 12:654-62. doi:10.1158/1535-7163. MCT-12-0771

34. Sorci G, Riuzzi F, Arcuri C, Giambanco I, Donato R. Amphoterin stimulates myogenesis and counteracts the antimyogenic factors basic fibroblast growth factor and S100B via RAGE binding. Mol Cell Biol (2004) 24:4880-94. doi:10.1128/MCB.24.11.4880-4894.2004

35. Boom A, Pochet R, Authelet M, Pradier L, Borghgraef P, Van Leuven F, et al. Astrocytic calcium/zinc binding protein S100A6 over expression in Alzheimer's disease and in PS1/APP transgenic mice models. Biochim Biophys Acta (2004) 1742:161-8. doi:10.1016/j.bbamcr.2004.09.011

36. Heizmann CW, Fritz G, Schafer BW. S100 proteins: structure, functions and pathology. Front Biosci (2002) 7:d1356-68. doi:10.2741/A846

37. Chazin WJ. Relating form and function of EF-hand calcium binding proteins. Acc Chem Res (2011) 44:171-9. doi:10.1021/ar100110d

38. Lindsey JC, Lusher ME, Anderton JA, Gilbertson RJ, Ellison DW, Clifford SC. Epigenetic deregulation of multiple $\mathrm{S} 100$ gene family members by differential hypomethylation and hypermethylation events in medulloblastoma. $\mathrm{Br}$ J Cancer (2007) 97:267-74. doi:10.1038/sj.bjc.6603852

39. Wang XH, Zhang LH, Zhong XY, Xing XF, Liu YQ, Niu ZJ, et al. S100A6 overexpression is associated with poor prognosis and is epigenetically up-regulated in gastric cancer. Am J Pathol (2010) 177:586-97. doi:10.2353/ ajpath.2010.091217

40. Wang Q, Williamson M, Bott S, Brookman-Amissah N, Freeman A, Nariculam J, et al. Hypomethylation of WNT5A, CRIP1 and S100P in prostate cancer. Oncogene (2007) 26:6560-5. doi:10.1038/sj.onc.1210472

41. Li JT, Wang LF, Zhao YL, Yang T, Li W, Zhao J, et al. Nuclear factor of activated $\mathrm{T}$ cells 5 maintained by Hotair suppression of miR-568 upregulates S100 calcium binding protein A4 to promote breast cancer metastasis. Breast Cancer Res (2014) 16:454. doi:10.1186/s13058-014-0454-2

42. Li W, Kong LB, Li JT, Guo ZY, Xue Q, Yang T, et al. MiR-568 inhibits the activation and function of CD4(+) T cells and Treg cells by targeting NFAT5. Int Immunol (2014) 26:269-81. doi:10.1093/intimm/dxt065

43. Donato R. Intracellular and extracellular roles of S100 proteins. Microsc Res Tech (2003) 60:540-51. doi:10.1002/jemt.10296

44. Edgeworth J, Gorman M, Bennett R, Freemont P, Hogg N. Identification of p8,14 as a highly abundant heterodimeric calcium binding protein complex of myeloid cells. J Biol Chem (1991) 266:7706-13. 
45. Averill MM, Barnhart S, Becker L, Li X, Heinecke JW, Leboeuf RC, et al. S100A9 differentially modifies phenotypic states of neutrophils, macrophages, and dendritic cells: implications for atherosclerosis and adipose tissue inflammation. Circulation (2011) 123:1216-26. doi:10.1161/ CIRCULATIONAHA.110.985523

46. Rahimi F, Hsu K, Endoh Y, Geczy CL. FGF-2, IL-1beta and TGF-beta regulate fibroblast expression of S100A8. FEBS $J$ (2005) 272:2811-27. doi:10.1111/j.1742-4658.2005.04703.x

47. Ingersoll MA, Spanbroek R, Lottaz C, Gautier EL, Frankenberger M, Hoffmann R, et al. Comparison of gene expression profiles between human and mouse monocyte subsets. Blood (2010) 115:e10-9. doi:10.1182/blood2009-07-235028

48. Yen T, Harrison CA, Devery JM, Leong S, Iismaa SE, Yoshimura T, et al. Induction of the $\mathrm{S} 100$ chemotactic protein, $\mathrm{CP}-10$, in murine microvascular endothelial cells by proinflammatory stimuli. Blood (1997) 90:4812-21.

49. McCormick MM, Rahimi F, Bobryshev YV, Gaus K, Zreiqat H, Cai H, et al. S100A8 and S100A9 in human arterial wall. Implications for atherogenesis. J Biol Chem (2005) 280:41521-9. doi:10.1074/jbc.M509442200

50. Yao D, Brownlee M. Hyperglycemia-induced reactive oxygen species increase expression of the receptor for advanced glycation end products (RAGE) and RAGE ligands. Diabetes (2010) 59:249-55. doi:10.2337/db09-0801

51. Grimbaldeston MA, Geczy CL, Tedla N, Finlay-Jones JJ, Hart PH. S100A8 induction in keratinocytes by ultraviolet A irradiation is dependent on reactive oxygen intermediates. JInvest Dermatol (2003) 121:1168-74. doi:10.1046/j.1523-1747.2003.12561.x

52. Schiopu A, Cotoi OS. S100A8 and S100A9: DAMPs at the crossroads between innate immunity, traditional risk factors, and cardiovascular disease. Mediators Inflamm (2013) 2013:828354. doi:10.1155/2013/828354

53. Hsu K, Champaiboon C, Guenther BD, Sorenson BS, Khammanivong A, Ross KF, et al. Anti-infective protective properties of S100 calgranulins. Antiinflamm Antiallergy Agents Med Chem (2009) 8:290-305. doi:10.2174/ 187152309789838975

54. Ravasi T, Hsu K, Goyette J, Schroder K, Yang Z, Rahimi F, et al. Probing the $\mathrm{S} 100$ protein family through genomic and functional analysis. Genomics (2004) 84:10-22. doi:10.1016/j.ygeno.2004.02.002

55. Goebeler M, Roth J, Van Den Bos C, Ader G, Sorg C. Increase of calcium levels in epithelial cells induces translocation of calcium-binding proteins migration inhibitory factor-related protein 8 (MRP8) and MRP14 to keratin intermediate filaments. Biochem J (1995) 309(Pt 2):419-24. doi:10.1042/ bj3090419

56. Stoll SW, Zhao X, Elder JT. EGF stimulates transcription of CaN19 (S100A2) in HaCaT keratinocytes. J Invest Dermatol (1998) 111:1092-7. doi:10.1046/ j.1523-1747.1998.00402.x

57. Mork G, Schjerven H, Mangschau L, Soyland E, Brandtzaeg P. Proinflammatory cytokines upregulate expression of calprotectin (L1 protein, MRP-8/ MRP-14) in cultured human keratinocytes. Br J Dermatol (2003) 149:484-91. doi:10.1046/j.1365-2133.2003.05536.x

58. Nukui T, Ehama R, Sakaguchi M, Sonegawa H, Katagiri C, Hibino T, et al. S100A8/A9, a key mediator for positive feedback growth stimulation of normal human keratinocytes. J Cell Biochem (2008) 104:453-64. doi:10.1002/ jcb. 21639

59. Bando M, Zou X, Hiroshima Y, Kataoka M, Ross KF, Shinohara Y, et al. Mechanism of interleukin-1alpha transcriptional regulation of S100A9 in a human epidermal keratinocyte cell line. Biochim Biophys Acta (2013) 1829:954-62. doi:10.1016/j.bbagrm.2013.03.010

60. Yao R, Lopez-Beltran A, Maclennan GT, Montironi R, Eble JN, Cheng L. Expression of $\mathrm{S} 100$ protein family members in the pathogenesis of bladder tumors. Anticancer Res (2007) 27:3051-8.

61. Nasser MW, Qamri Z, Deol YS, Ravi J, Powell CA, Trikha P, et al. S100A7 enhances mammary tumorigenesis through upregulation of inflammatory pathways. Cancer Res (2012) 72:604-15. doi:10.1158/0008-5472.CAN$11-0669$

62. Glaser R, Harder J, Lange H, Bartels J, Christophers E, Schroder JM. Antimicrobial psoriasin (S100A7) protects human skin from Escherichia coli infection. Nat Immunol (2005) 6:57-64. doi:10.1038/ni1142

63. Kim JH, Oh SH, Kim EJ, Park SJ, Hong SP, Cheon JH, et al. The role of myofibroblasts in upregulation of S100A8 and S100A9 and the differentiation of myeloid cells in the colorectal cancer microenvironment. Biochem Biophys Res Commun (2012) 423:60-6. doi:10.1016/j.bbrc.2012.05.081
64. Dapunt U, Gaida MM, Meyle E, Prior B, Hansch GM. Activation of phagocytic cells by Staphylococcus epidermidis biofilms: effects of extracellular matrix proteins and the bacterial stress protein GroEL on netosis and MRP14 release. Pathog Dis (2016) 74:ftw035. doi:10.1093/femspd/ftw035

65. Kligman D, Hilt DC. The S100 protein family. Trends Biochem Sci (1988) 13:437-43. doi:10.1016/0968-0004(88)90218-6

66. Winningham-Major F, Staecker JL, Barger SW, Coats S, Van Eldik LJ. Neurite extension and neuronal survival activities of recombinant $S 100$ beta proteins that differ in the content and position of cysteine residues. J Cell Biol (1989) 109:3063-71. doi:10.1083/jcb.109.6.3063

67. Chan JK, Roth J, Oppenheim JJ, Tracey KJ, Vogl T, Feldmann M, et al. Alarmins: awaiting a clinical response. J Clin Invest (2012) 122:2711-9. doi:10.1172/JCI62423

68. Newton K, Dixit VM. Signaling in innate immunity and inflammation. Cold Spring Harb Perspect Biol (2012) 4:a006049. doi:10.1101/cshperspect.a006049

69. de Haan JJ, Smeets MB, Pasterkamp G, Arslan F. Danger signals in the initiation of the inflammatory response after myocardial infarction. Mediators Inflamm (2013) 2013:206039. doi:10.1155/2013/206039

70. Foell D, Wittkowski H, Vogl T, Roth J. S100 proteins expressed in phagocytes: a novel group of damage-associated molecular pattern molecules. J Leukoc Biol (2007) 81:28-37. doi:10.1189/jlb.0306170

71. Schmidt AM, Hofmann M, Taguchi A, Yan SD, Stern DM. RAGE: a multiligand receptor contributing to the cellular response in diabetic vasculopathy and inflammation. Semin Thromb Hemost (2000) 26:485-93. doi:10.105 5/s-2000-13204

72. Ryckman C, Vandal K, Rouleau P, Talbot M, Tessier PA. Proinflammatory activities of S100: proteins S100A8, S100A9, and S100A8/A9 induce neutrophil chemotaxis and adhesion. J Immunol (2003) 170:3233-42. doi:10.4049/ jimmunol.170.6.3233

73. Ghavami S, Eshragi M, Ande SR, Chazin WJ, Klonisch T, Halayko AJ, et al. S100A8/A9 induces autophagy and apoptosis via ROS-mediated cross-talk between mitochondria and lysosomes that involves BNIP3. Cell Res (2010) 20:314-31. doi:10.1038/cr.2009.129

74. Sunahori K, Yamamura M, Yamana J, Takasugi K, Kawashima M, Yamamoto H, et al. The S100A8/A9 heterodimer amplifies proinflammatory cytokine production by macrophages via activation of nuclear factor kappa B and p38 mitogen-activated protein kinase in rheumatoid arthritis. Arthritis Res Ther (2006) 8:R69. doi:10.1186/ar1939

75. Eue I, Pietz B, Storck J, Klempt M, Sorg C. Transendothelial migration of 27E10+ human monocytes. Int Immunol (2000) 12:1593-604. doi:10.1093/ intimm/12.11.1593

76. Nisapakultorn K, Ross KF, Herzberg MC. Calprotectin expression inhibits bacterial binding to mucosal epithelial cells. Infect Immun (2001) 69: 3692-6. doi:10.1128/IAI.69.6.3692-3696.2001

77. Newton RA, Hogg N. The human S100 protein MRP-14 is a novel activator of the beta 2 integrin Mac-1 on neutrophils. J Immunol (1998) 160:1427-35.

78. Manitz MP, Horst B, Seeliger S, Strey A, Skryabin BV, Gunzer M, et al. Loss of S100A9 (MRP14) results in reduced interleukin-8-induced CD11b surface expression, a polarized microfilament system, and diminished responsiveness to chemoattractants in vitro. Mol Cell Biol (2003) 23:1034-43. doi:10.1128/ MCB.23.3.1034-1043.2003

79. Garrett SC, Varney KM, Weber DJ, Bresnick AR. S100A4, a mediator of metastasis. J Biol Chem (2006) 281:677-80. doi:10.1074/jbc.R500017200

80. Boye K, Maelandsmo GM. S100A4 and metastasis: a small actor playing many roles. Am JPathol (2010) 176:528-35. doi:10.2353/ajpath.2010. 090526

81. Malashkevich VN, Dulyaninova NG, Ramagopal UA, Liriano MA, VarneyKM, Knight D, et al. Phenothiazines inhibit S100A4 function by inducing protein oligomerization. Proc Natl Acad Sci U S A (2010) 107:8605-10. doi:10.1073/ pnas.0913660107

82. Yang Z, Yan WX, Cai H, Tedla N, Armishaw C, Di Girolamo N, et al. S100A12 provokes mast cell activation: a potential amplification pathway in asthma and innate immunity. J Allergy Clin Immunol (2007) 119:106-14. doi:10.1016/j.jaci.2006.08.021

83. Pollard JW. Tumour-educated macrophages promote tumour progression and metastasis. Nat Rev Cancer (2004) 4:71-8. doi:10.1038/nrc1256

84. Condeelis J, Pollard JW. Macrophages: obligate partners for tumor cell migration, invasion, and metastasis. Cell (2006) 124:263-6. doi:10.1016/j. cell.2006.01.007 
85. Sica A, Bronte V. Altered macrophage differentiation and immune dysfunction in tumor development. J Clin Invest (2007) 117:1155-66. doi:10.1172/ JCI31422

86. Dandekar RC, Kingaonkar AV, Dhabekar GS. Role of macrophages in malignancy. Ann Maxillofac Surg (2011) 1:150-4. doi:10.4103/2231-0746. 92782

87. Sica A, Schioppa T, Mantovani A, Allavena P. Tumour-associated macrophages are a distinct M2 polarised population promoting tumour progression: potential targets of anti-cancer therapy. Eur J Cancer (2006) 42:717-27. doi:10.1016/j.ejca.2006.01.003

88. Lewis CE, Hughes R. Inflammation and breast cancer. Microenvironmental factors regulating macrophage function in breast tumours: hypoxia and angiopoietin-2. Breast Cancer Res (2007) 9:209. doi:10.1186/bcr1679

89. Phipps KD, Surette AP, O'Connell PA, Waisman DM. Plasminogen receptor S100A10 is essential for the migration of tumor-promoting macrophages into tumor sites. Cancer Res (2011) 71:6676-83. doi:10.1158/0008-5472. CAN-11-1748

90. O'Connell PA, Surette AP, Liwski RS, Svenningsson P, Waisman DM. S100A10 regulates plasminogen-dependent macrophage invasion. Blood (2010) 116:1136-46. doi:10.1182/blood-2010-01-264754

91. Hashimoto S, Suzuki T, Dong HY, Nagai S, Yamazaki N, Matsushima K. Serial analysis of gene expression in human monocyte-derived dendritic cells. Blood (1999) 94:845-52.

92. Cheng P, Corzo CA, Luetteke N, Yu B, Nagaraj S, Bui MM, et al. Inhibition of dendritic cell differentiation and accumulation of myeloid-derived suppressor cells in cancer is regulated by S100A9 protein. J Exp Med (2008) 205:2235-49. doi:10.1084/jem.20080132

93. Lagasse E, Weissman IL. Mouse MRP8 and MRP14, two intracellular calcium-binding proteins associated with the development of the myeloid lineage. Blood (1992) 79:1907-15.

94. Khammanivong A, Wang C, Sorenson BS, Ross KF, Herzberg MC. S100A8/ A9 (calprotectin) negatively regulates $\mathrm{G} 2 / \mathrm{M}$ cell cycle progression and growth of squamous cell carcinoma. PLoS One (2013) 8:e69395. doi:10.1371/ journal.pone.0069395

95. Dapunt U, Giese T, Maurer S, Stegmaier S, Prior B, Hansch GM, et al. Neutrophil-derived MRP-14 is up-regulated in infectious osteomyelitis and stimulates osteoclast generation. J Leukoc Biol (2015) 98:575-82. doi:10.1189/ jlb.3VMA1014-482R

96. Sade-Feldman M, Kanterman J, Ish-Shalom E, Elnekave M, Horwitz E, Baniyash M. Tumor necrosis factor-alpha blocks differentiation and enhances suppressive activity of immature myeloid cells during chronic inflammation. Immunity (2013) 38:541-54. doi:10.1016/j.immuni.2013.02.007

97. Goyette J, Yan WX, Yamen E, Chung YM, Lim SY, Hsu K, et al. Pleiotropic roles of S100A12 in coronary atherosclerotic plaque formation and rupture. J Immunol (2009) 183:593-603. doi:10.4049/jimmunol.0900373

98. Abbas A, Aukrust P, Dahl TB, Bjerkeli V, Sagen EB, Michelsen A, et al. High levels of S100A12 are associated with recent plaque symptomatology in patients with carotid atherosclerosis. Stroke (2012) 43:1347-53. doi:10.1161/ STROKEAHA.111.642256

99. Zhao P, Wu M, Yu H, Huang Y, Wang Y, Wang W, et al. Serum S100A12 levels are correlated with the presence and severity of coronary artery disease in patients with type 2 diabetes mellitus. J Investig Med (2013) 61:861-6. doi:10.2310/JIM.0b013e318292fble

100. Broome AM, Ryan D, Eckert RL. S100 protein subcellular localization during epidermal differentiation and psoriasis. J Histochem Cytochem (2003) 51:675-85. doi:10.1177/002215540305100513

101. Batycka-Baran A, Hattinger E, Zwicker S, Summer B, Zack Howard OM, Thomas P, et al. Leukocyte-derived koebnerisin (S100A15) and psoriasin (S100A7) are systemic mediators of inflammation in psoriasis. J Dermatol Sci (2015) 79:214-21. doi:10.1016/j.jdermsci.2015.05.007

102. Sroussi HY, Kohler GA, Agabian N, Villines D, Palefsky JM. Substitution of methionine 63 or 83 in S100A9 and cysteine 42 in S100A8 abrogate the antifungal activities of S100A8/A9: potential role for oxidative regulation. FEMS Immunol Med Microbiol (2009) 55:55-61. doi:10.1111/ j.1574-695X.2008.00498.X

103. Croce K, Gao H, Wang Y, Mooroka T, Sakuma M, Shi C, et al. Myeloid-related protein-8/14 is critical for the biological response to vascular injury. Circulation (2009) 120:427-36. doi:10.1161/CIRCULATIONAHA.108.814582
104. Wu Y, Li Y, Zhang C, A X, Wang Y, Cui W, et al. S100a8/a9 released by $\mathrm{CD} 11 \mathrm{~b}+\mathrm{Gr} 1+$ neutrophils activates cardiac fibroblasts to initiate angiotensin II-induced cardiac inflammation and injury. Hypertension (2014) 63:1241-50. doi:10.1161/HYPERTENSIONAHA.113.02843

105. van Lent PL, Blom AB, Schelbergen RF, Sloetjes A, Lafeber FP, Lems WF, et al. Active involvement of alarmins S100A8 and S100A9 in the regulation of synovial activation and joint destruction during mouse and human osteoarthritis. Arthritis Rheum (2012) 64:1466-76. doi:10.1002/ art. 34315

106. Schelbergen RF, De Munter W, Van Den Bosch MH, Lafeber FP, Sloetjes A, Vogl T, et al. Alarmins S100A8/S100A9 aggravate osteophyte formation in experimental osteoarthritis and predict osteophyte progression in early human symptomatic osteoarthritis. Ann Rheum Dis (2016) 75:218-25. doi:10.1136/annrheumdis-2014-205480

107. Le Hir M, Hegyi I, Cueni-Loffing D, Loffing J, Kaissling B. Characterization of renal interstitial fibroblast-specific protein 1/S100A4-positive cells in healthy and inflamed rodent kidneys. Histochem Cell Biol (2005) 123:335-46. doi:10.1007/s00418-005-0788-z

108. Schneider M, Kostin S, Strom CC, Aplin M, Lyngbaek S, Theilade J, et al. S100A4 is upregulated in injured myocardium and promotes growth and survival of cardiac myocytes. Cardiovasc Res (2007) 75:40-50. doi:10.1016/j. cardiores.2007.03.027

109. Ma W, Lee SE, Guo J, Qu W, Hudson BI, Schmidt AM, et al. RAGE ligand upregulation of VEGF secretion in ARPE-19 cells. Invest Ophthalmol Vis Sci (2007) 48:1355-61. doi:10.1167/iovs.06-0738

110. Huttunen HJ, Kuja-Panula J, Sorci G, Agneletti AL, Donato R, Rauvala H. Coregulation of neurite outgrowth and cell survival by amphoterin and S100 proteins through receptor for advanced glycation end products (RAGE) activation. JBiol Chem (2000) 275:40096-105. doi:10.1074/jbc.M006 993200

111. Shaw SS, Schmidt AM, Banes AK, Wang X, Stern DM, Marrero MB. S100BRAGE-mediated augmentation of angiotensin II-induced activation of JAK2 in vascular smooth muscle cells is dependent on PLD2. Diabetes (2003) 52:2381-8. doi:10.2337/diabetes.52.9.2381

112. Sorci G, Skarstein F, Morand S, Hugot JP. Correlated evolution between host immunity and parasite life histories in primates and oxyurid parasites. Proc Biol Sci (2003) 270:2481-4. doi:10.1098/rspb.2003.2536

113. Riuzzi F, Sorci G, Donato R. S100B stimulates myoblast proliferation and inhibits myoblast differentiation by independently stimulating ERK1/2 and inhibiting p38 MAPK. J Cell Physiol (2006) 207:461-70. doi:10.1002/ jcp. 20580

114. Riuzzi F, Sorci G, Donato R. The amphoterin (HMGB1)/receptor for advanced glycation end products (RAGE) pair modulates myoblast proliferation, apoptosis, adhesiveness, migration, and invasiveness. Functional inactivation of RAGE in L6 myoblasts results in tumor formation in vivo. J Biol Chem (2006) 281:8242-53. doi:10.1074/jbc.M509436200

115. Perera C, Mcneil HP, Geczy CL. S100 calgranulins in inflammatory arthritis. Immunol Cell Biol (2010) 88:41-9. doi:10.1038/icb.2009.88

116. Odink K, Cerletti N, Bruggen J, Clerc RG, Tarcsay L, Zwadlo G, et al. Two calcium-binding proteins in infiltrate macrophages of rheumatoid arthritis. Nature (1987) 330:80-2. doi:10.1038/330080a0

117. Frosch M, Strey A, Vogl T, Wulffraat NM, Kuis W, Sunderkotter C, et al. Myeloid-related proteins 8 and 14 are specifically secreted during interaction of phagocytes and activated endothelium and are useful markers for monitoring disease activity in pauciarticular-onset juvenile rheumatoid arthritis. Arthritis Rheum (2000) 43:628-37. doi:10.1002/ 1529-0131(200003)43:3<628::AID-ANR20>3.0.CO;2-X

118. Zreiqat H, Belluoccio D, Smith MM, Wilson R, Rowley LA, Jones K, et al. S100A8 and S100A9 in experimental osteoarthritis. Arthritis Res Ther (2010) 12:R16. doi:10.1186/ar2917

119. van Lent PL, Grevers L, Blom AB, Sloetjes A, Mort JS, Vogl T, et al. Myeloidrelated proteins S100A8/S100A9 regulate joint inflammation and cartilage destruction during antigen-induced arthritis. Ann Rheum Dis (2008) 67:1750-8. doi:10.1136/ard.2007.077800

120. Wolf R, Mirmohammadsadegh A, Walz M, Lysa B, Tartler U, Remus R, et al. Molecular cloning and characterization of alternatively spliced mRNA isoforms from psoriatic skin encoding a novel member of the S100 family. FASEB J (2003) 17:1969-71. doi:10.1096/fj.03-0148fje 
121. Fessatou S, Fagerhol MK, Roth J, Stamoulakatou A, Kitra V, Hadarean M, et al. Severe anemia and neutropenia associated with hyperzincemia and hypercalprotectinemia. J Pediatr Hematol Oncol (2005) 27:477-80. doi:10.1097/01.mph.0000179958.19524.9c

122. Isidor B, Poignant S, Corradini N, Fouassier M, Quartier P, Roth J, et al. Hyperzincemia and hypercalprotectinemia: unsuccessful treatment with tacrolimus.ActaPaediatr(2009)98:410-2.doi:10.1111/j.1651-2227.2008.01092.x

123. Vaos G, Kostakis ID, Zavras N, Chatzemichael A. The role of calprotectin in pediatric disease. Biomed Res Int (2013) 2013:542363. doi:10.1155/2013/542363

124. Moroz OV, Antson AA, Grist SJ, Maitland NJ, Dodson GG, Wilson KS, et al. Structure of the human S100A12-copper complex: implications for host-parasite defence. Acta Crystallogr D Biol Crystallogr (2003) 59:859-67. doi:10.1107/S0907444903004700

125. Realegeno S, Kelly-Scumpia KM, Dang AT, Lu J, Teles R, Liu PT, et al. S100A12 is part of the antimicrobial network against Mycobacterium leprae in human macrophages. PLoS Pathog (2016) 12:e1005705. doi:10.1371/ journal.ppat.1005705

126. Haley KP, Delgado AG, Piazuelo MB, Mortensen BL, Correa P, Damo SM, et al. The human antimicrobial protein calgranulin $\mathrm{C}$ participates in control of Helicobacter pylori growth and regulation of virulence. Infect Immun (2015) 83:2944-56. doi:10.1128/IAI.00544-15

127. Kang JH, Hwang SM, Chung IY. S100A8, S100A9 and S100A12 activate airway epithelial cells to produce MUC5AC via extracellular signal-regulated kinase and nuclear factor-kappaB pathways. Immunology (2015) 144:79-90. doi:10.1111/imm. 12352

128. Nagareddy PR, Murphy AJ, Stirzaker RA, Hu Y, Yu S, Miller RG, et al. Hyperglycemia promotes myelopoiesis and impairs the resolution of atherosclerosis. Cell Metab (2013) 17:695-708. doi:10.1016/j.cmet.2013.04.001

129. Mortensen OH, Nielsen AR, Erikstrup C, Plomgaard P, Fischer CP, KroghMadsen R, et al. Calprotectin - a novel marker of obesity. PLoS One (2009) 4:e7419. doi:10.1371/journal.pone.0007419

130. Catalan V, Gomez-Ambrosi J, Rodriguez A, Ramirez B, Rotellar F, Valenti V, et al. Increased levels of calprotectin in obesity are related to macrophage content: impact on inflammation and effect of weight loss. Mol Med (2011) 17:1157-67. doi:10.2119/molmed.2011.00144

131. Asakura M, Karaki F, Fujii H, Atsuda K, Itoh T, Fujiwara R. Vildagliptin and its metabolite M20.7 induce the expression of S100A8 and S100A9 in human hepatoma HepG2 and leukemia HL-60 cells. Sci Rep (2016) 6:35633. doi:10.1038/srep35633

132. van den Bos C, Roth J, Koch HG, Hartmann M, Sorg C. Phosphorylation of MRP14, an S100 protein expressed during monocytic differentiation, modulates $\mathrm{Ca}(2+)$-dependent translocation from cytoplasm to membranes and cytoskeleton. J Immunol (1996) 156:1247-54.

133. Siegenthaler G, Roulin K, Chatellard-Gruaz D, Hotz R, Saurat JH, Hellman U, et al. A heterocomplex formed by the calcium-binding proteins MRP8 (S100A8) and MRP14 (S100A9) binds unsaturated fatty acids with high affinity. J Biol Chem (1997) 272:9371-7. doi:10.1074/jbc.272.14.9371

134. Yang Z, Tao T, Raftery MJ, Youssef P, Di Girolamo N, Geczy CL. Proinflammatory properties of the human S100 protein S100A12. J Leukoc Biol (2001) 69:986-94

135. Foell D, Seeliger S, Vogl T, Koch HG, Maschek H, Harms E, et al. Expression of S100A12 (EN-RAGE) in cystic fibrosis. Thorax (2003) 58:613-7. doi:10.1136/ thorax.58.7.613

136. Mocellin S, Zavagno G, Nitti D. The prognostic value of serum S100B in patients with cutaneous melanoma: a meta-analysis. Int J Cancer (2008) 123:2370-6. doi:10.1002/ijc.23794

137. Gazzolo D, Michetti F. Perinatal S100B protein assessment in human unconventional biological fluids: a minireview and new perspectives. Cardiovasc Psychiatry Neurol (2010) 2010:703563. doi:10.1155/2010/703563

138. Heizmann CW. The multifunctional S100 protein family. Methods Mol Biol (2002) 172:69-80. doi:10.1385/1-59259-183-3:069

139. Oesterle A, Bowman MA. S100A12 and the S100/calgranulins: emerging biomarkers for atherosclerosis and possibly therapeutic targets. Arterioscler Thromb Vasc Biol (2015) 35:2496-507. doi:10.1161/ATVBAHA.115.302072

140. Bogdanova MV, Rameev VV, Kozlovskaya LV, Fedorov ES, Salugina SO. [Serum calgranulin $\mathrm{C}$ is a highly sensitive autoinflammation activity indicator in patients with familial periodic fevers]. Ter Arkh (2016) 88:58-64. doi:10.17116/terarkh201688658-64

141. Kallinich T, Wittkowski H, Keitzer R, Roth J, Foell D. Neutrophil-derived S100A12 as novel biomarker of inflammation in familial Mediterranean fever. Ann Rheum Dis (2010) 69:677-82. doi:10.1136/ard.2009.114363

142. Geven EJ, Van Den Bosch MH, Di Ceglie I, Ascone G, Abdollahi-Roodsaz S, Sloetjes AW, et al. S100A8/A9, a potent serum and molecular imaging biomarker for synovial inflammation and joint destruction in seronegative experimental arthritis. Arthritis Res Ther (2016) 18:247. doi:10.1186/ s13075-016-1121-z

143. Ionita MG, Vink A, Dijke IE, Laman JD, Peeters W, Van Der Kraak PH, et al. High levels of myeloid-related protein 14 in human atherosclerotic plaques correlate with the characteristics of rupture-prone lesions. Arterioscler Thromb Vasc Biol (2009) 29:1220-7. doi:10.1161/ATVBAHA.109.190314

144. Xia GL, Wang YK, Huang ZQ. The correlation of serum myeloid-related protein-8/14 and eosinophil cationic protein in patients with coronary artery disease. Biomed Res Int (2016) 2016:4980251. doi:10.1155/2016/ 4980251

145. Wittkowski H, Kuemmerle-Deschner JB, Austermann J, Holzinger D, Goldbach-Mansky R, Gramlich K, et al. MRP8 and MRP14, phagocytespecific danger signals, are sensitive biomarkers of disease activity in cryopyrin-associated periodic syndromes. Ann Rheum Dis (2011) 70:2075-81. doi:10.1136/ard.2011.152496

146. Holzinger D, Frosch M, Kastrup A, Prince FH, Otten MH, Van SuijlekomSmit LW, et al. The toll-like receptor 4 agonist MRP8/14 protein complex is a sensitive indicator for disease activity and predicts relapses in systemic-onset juvenile idiopathic arthritis. Ann Rheum Dis (2012) 71:974-80. doi:10.1136/ annrheumdis-2011-200598

147. Hurnakova J, Zavada J, Hanova P, Hulejova H, Klein M, Mann H, et al. Serum calprotectin (S100A8/9): an independent predictor of ultrasound synovitis in patients with rheumatoid arthritis. Arthritis Res Ther (2015) 17:252. doi:10.1186/s13075-015-0764-5

148. Shakeri M, Mahdkhah A, Panahi F. S100B protein as a post-traumatic biomarker for prediction of brain death in association with patient outcomes. Arch Trauma Res (2013) 2:76-80. doi:10.5812/atr.8549

149. Pelinka LE, Kroepfl A, Leixnering M, Buchinger W, Raabe A, Redl H. GFAP versus $\mathrm{S} 100 \mathrm{~B}$ in serum after traumatic brain injury: relationship to brain damage and outcome. J Neurotrauma (2004) 21:1553-61. doi:10.1089/ neu.2004.21.1553

150. Dang X, Guan L, Hu W, Du G, Li J. S100B ranks as a new marker of multiple traumas in patients and may accelerate its development by regulating endothelial cell dysfunction. Int J Clin Exp Pathol (2014) 7:3818-26.

151. Blyth BJ, Farhavar A, Gee C, Hawthorn B, He H, Nayak A, et al. Validation of serum markers for blood-brain barrier disruption in traumatic brain injury. J Neurotrauma (2009) 26:1497-507. doi:10.1089/neu.2008-0738

152. Egea-Guerrero JJ, Revuelto-Rey J, Gordillo-Escobar E, Rodriguez-Rodriguez A, Enamorado-Enamorado J, Ruiz De Azua Lopez Z, et al. Serologic behavior of S100B protein in patients who are brain dead: preliminary results. Transplant Proc (2013) 45:3569-72. doi:10.1016/j.transproceed.2013.10.021

153. Thelin EP, Jeppsson E, Frostell A, Svensson M, Mondello S, Bellander BM, et al. Utility of neuron-specific enolase in traumatic brain injury; relations to S100B levels, outcome, and extracranial injury severity. Crit Care (2016) 20:285. doi:10.1186/s13054-016-1450-y

154. Weglewski A, Ryglewicz D, Mular A, Jurynczyk J. [Changes of protein S100B serum concentration during ischemic and hemorrhagic stroke in relation to the volume of stroke lesion]. Neurol Neurochir Pol (2005) 39:310-7.

155. Kaca-Orynska M, Tomasiuk R, Friedman A. Neuron-specific enolase and S100B protein as predictors of outcome in ischaemic stroke. Neurol Neurochir Pol (2010) 44:459-63. doi:10.1016/S0028-3843(14)60136-5

156. Esposito G, Imitola J, Lu J, De Filippis D, Scuderi C, Ganesh VS, et al. Genomic and functional profiling of human Down syndrome neural progenitors implicates S100B and aquaporin 4 in cell injury. Hum Mol Genet (2008) 17:440-57. doi:10.1093/hmg/ddm322

157. Lu J, Esposito G, Scuderi C, Steardo L, Delli-Bovi LC, Hecht JL, et al. S100B and APP promote a gliocentric shift and impaired neurogenesis in Down syndrome neural progenitors. PLoS One (2011) 6:e22126. doi:10.1371/ journal.pone. 0022126 
158. Gogas H, Eggermont AM, Hauschild A, Hersey P, Mohr P, Schadendorf D, et al. Biomarkers in melanoma. Ann Oncol (2009) 20(Suppl 6):vi8-13. doi:10.1093/annonc/mdp251

159. Shishibori T, Oyama Y, Matsushita O, Yamashita K, Furuichi H, Okabe A, et al. Three distinct anti-allergic drugs, amlexanox, cromolyn and tranilast, bind to S100A12 and S100A13 of the S100 protein family. Biochem J (1999) 338(Pt 3):583-9. doi:10.1042/bj3380583

160. Semov A, Moreno MJ, Onichtchenko A, Abulrob A, Ball M, Ekiel I, et al. Metastasis-associated protein S100A4 induces angiogenesis through interaction with Annexin II and accelerated plasmin formation. J Biol Chem (2005) 280:20833-41. doi:10.1074/jbc.M412653200

161. Faries MB, Gupta RK, Ye X, Lee C, Yee R, Leopoldo Z, et al. A comparison of 3 tumor markers (MIA, TA90IC, S100B) in stage III melanoma patients. Cancer Invest (2007) 25:285-93. doi:10.1080/07357900701208634

162. Fernandez-Fernandez MR, Veprintsev DB, Fersht AR. Proteins of the S100 family regulate the oligomerization of p53 tumor suppressor. Proc Natl Acad Sci U S A (2005) 102:4735-40. doi:10.1073/pnas.0501459102

163. Gieldon A, Mori M, Del Conte R. Theoretical study on binding of S100B protein. J Mol Model (2007) 13:1123-31. doi:10.1007/s00894-007-0231-6

164. Most P, Boerries M, Eicher C, Schweda C, Ehlermann P, Pleger ST, et al. Extracellular S100A1 protein inhibits apoptosis in ventricular cardiomyocytes via activation of the extracellular signal-regulated protein kinase $1 / 2$ (ERK1/2). J Biol Chem (2003) 278:48404-12. doi:10.1074/jbc.M308587200
165. Pleger ST, Shan C, Ksienzyk J, Bekeredjian R, Boekstegers P, Hinkel R, et al. Cardiac AAV9-S100A1 gene therapy rescues post-ischemic heart failure in a preclinical large animal model. Sci Transl Med (2011) 3:92ra64. doi:10.1126/ scitranslmed.3002097

166. Ritterhoff J, Most P. Targeting S100A1 in heart failure. Gene Ther (2012) 19:613-21. doi:10.1038/gt.2012.8

167. Tsumura H, Akimoto M, Kiyota H, Ishii Y, Ishikura H, Honma Y. Gene expression profiles in differentiating leukemia cells induced by methyl jasmonate are similar to those of cytokinins and methyl jasmonate analogs induce the differentiation of human leukemia cells in primary culture. Leukemia (2009) 23:753-60. doi:10.1038/leu.2008.347

Conflict of Interest Statement: The authors declare that the research was conducted in the absence of any commercial or financial relationships that could be construed as a potential conflict of interest.

Copyright (c) 2018 Xia, Braunstein, Toomey, Zhong and Rao. This is an open-access article distributed under the terms of the Creative Commons Attribution License (CC BY). The use, distribution or reproduction in other forums is permitted, provided the original author(s) or licensor are credited and that the original publication in this journal is cited, in accordance with accepted academic practice. No use, distribution or reproduction is permitted which does not comply with these terms. 